Original Contribution

\title{
CHARACTERISTICS OF THE ONSET OF PUBERTY IN MALE KIDS OF THREE BREEDS
}

\author{
S. Stoycheva*, P. Zunev, Ts. Bancheva \\ Research Institute of Mountain Stockbreeding and Agriculture, Troyan, Bulgaria
}

\begin{abstract}
The aim of the study was to trace the development of some morphological characteristics of puberty and their development up to the 44th week as well as the relationships between them, to find the best subjects based on the phenotype.

Weaning weight was measured as well as their weight once a month until the 44th week.

Measuring the circumference of the scrotum of experimental young bucks was performed weekly from weaning to 44 weeks of age. Monitoring of the release of the penis from the foreskin was performed weekly from weaning until the time of its full release. The average value of the circumference of the scrotum increased from the 12th week to the 39th week in total for all animals (from 15.8 to $28.4 \mathrm{~cm}$ ), as well as by breed (BWD - 16.5 to $31 \mathrm{~cm}$ ), (Togenburg - 15.5 to $28.5 \mathrm{~cm}$ ) and (Anglo-Nubian 15.8 to 26.1 $\mathrm{cm})(\mathrm{p}>0.05)$. The variation of the trait was low throughout the study period.

The earliest complete release of the penis in our study was observed in the male kids BWD breed -16 weeks. Togenburg kids reached full release at - 18 weeks. In AN kids, the release was at -24 weeks. The correlation coefficient showed a very strong reliable positive relationship between the studied factors in all three studied breeds. Testicular size and body weight could be used as a determining factor in the selection of prepubertal male kids.
\end{abstract}

Key words: Scrotal circumference, young male goats, puberty, sexual maturity

\section{INTRODUCTION}

Goat farming is an industry that has become of growing interest to farmers worldwide in recent years. The growing demand for delicatessen, dietary and ecologically clean goat milk products create better prospects for the realization of the products from the goat farms.

Along with milk production, one of the main factors that determine the economic efficiency of goat farms is their reproductive capacity. Determining the age at which sexual maturity of male breeders occurs is of paramount importance for the optimal use of their potential (1). In order to reach its full reproductive potential, the animal must reach sexual maturity - it shows sexual instinct, mating ability and semen quality (2). Puberty

\footnotetext{
*Correspondence to: S. Stoycheva, Research Institute of Mountain Stockbreeding and Agriculture, 281 Vasil Levski Str., 5600 Troyan, Bulgaria,e-mail: s.e.stoycheva@abv.bg
}

is characterized by the onset of reproductive activity. It is crucial in the early selection of animals for breeding and the aim is to be able to use them for a longer period of time, as well as for the organization of work on the farm. (3, $2,4)$.

Tracking the growth and development of the male breeder by the change of the parameters of the exterior allows breeders to distinguish early maturing individuals (5). According to them, the exact age of the start of puberty can be postponed until the animals reach a certain body size. Birth weight, weaning weight, scrotal circumference, separation of the penis from the foreskin, and semen characteristics are important indicators of puberty in goats $(6$, 7). Also, the body weight gives an idea of the development of the kids as well as their needed ration and evaluation of the animal at a certain age, etc. (8). The scrotal circumference is an indicator that indirectly determines the size of the testicles. According to (4) regardless of 
breed and latitude, the testicular growth of bucks is closely related to live weight and age of bucks. (9) Mention that bucks that have a naturally high libido can be selected for breeding based on the measurement of the scrotal circumference.

Male breeding animals can be easily evaluated in field conditions, taking into account their physical condition, an examination of the external genitalia, their ability to mate and their sperm production (10).

The Bulgarian White Dairy Goat breed is the main dairy breed bred in Bulgaria. Despite its importance for goat breeding, there is not enough data in the literature characterizing the morphological and physiological changes occurring at the beginning of puberty in this breed, as well as in the Togenburg and AngloNubian breeds in our country.

The aim of the study was to trace the development of some morphological characteristics of puberty and their development up to the 44th week as well as the relationships between them, to find the best subjects based on the phenotype.

\section{MATERIALS AND METHODS}

The study was conducted in the goat farm of the Research Institute of Mountain Stockbreeding and Agriculture in Troyan, Bulgaria during the period - February 2019 to February 2020. For this purpose, 12 clinically healthy male animals (4 from the Bulgarian White Dairy breed, 4 from the Togenburg and 4 Anglo-Nubian breeds), equal in age and live weight, were studied. Immediately after birth, the kids were weighed with an electronic scale. Weaning weight was measured as well as their weight once a month until the 44th week. Age was determined by records in the studbooks.

Until the third day after birth, the kids were raised with their mother in individual boxes, where colostrum was able to be suckled freely around the clock. On the fourth day, they were separated from the mother and placed in group boxes of 10 kids where they were fed with goat's milk with buckets with five pacifiers. After the 25th day, good quality meadow and alfalfa hay was given to the kids. Later, they became accustomed to eating a concentrated mixture. After weaning, the animals were fed ground alfalfa hay and a concentrated mixture. The kids had free access to drinking water. All veterinary measures have been taken.

Scrotal circumference - measuring the circumference of the scrotum of experimental young bucks was performed weekly from weaning to 44 weeks of age with a measuring tape $(\mathrm{cm})$. To measure the scrotal circumference, the testicles were pushed into the bottom of the scrotum, with the fingers placed on the side of the cervix of the scrotum and pushed out ventrally. The tape formed a contour and slid along the scrotum, and the circumference was measured by pulling the tape tightly around its largest diameter (11).

\section{Separation of the penis from the foreskin -} monitoring of the release of the penis from the foreskin was performed weekly from weaning until the time of its full release. The release was rated on a scale of 1 to 5 (12) as the animals were placed in a sitting position, the foreskin was pulled down to reveal the penis: (1) it is an infantile condition, (2) a free urethral process, (3) free tip of the glans penis, (4) free to bottom of the glans penis or slightly below and (5) adult condition.

One-way ANOVA was used for statistical comparison. Relationships between investigation the parameters of male kids were determined with Pearson correlation analysis.

\section{RESULTS AND DISCUSSIONS}

The results (Figure 1) revealed that the average value of the circumference of the scrotum increased from the 12th week to the 39th week in total for all animals (from 15.8 to $28.4 \mathrm{~cm}$ ), as well as by breed (Bulgarian White Dairy - 16.5 to $31 \mathrm{~cm}$ ), (Togenburg - 15.5 to $28.5 \mathrm{~cm}$ ) and (Anglo-Nubian 15.8 to $26.1 \mathrm{~cm}$ ) (p> 0.05). After this period the values remained constant with slight variations in the breed Bulgarian White Dairy. The variation of the trait was low throughout the study period (Table 1).

What impressed us was that there were alternating periods of significant growth and stability. This coincides with the results obtained by (4) in Anglo-Nubian bucks aged 12 to 44 weeks, and by (13) in native Brazilian goats. 
STOYCHEVA S., et al.

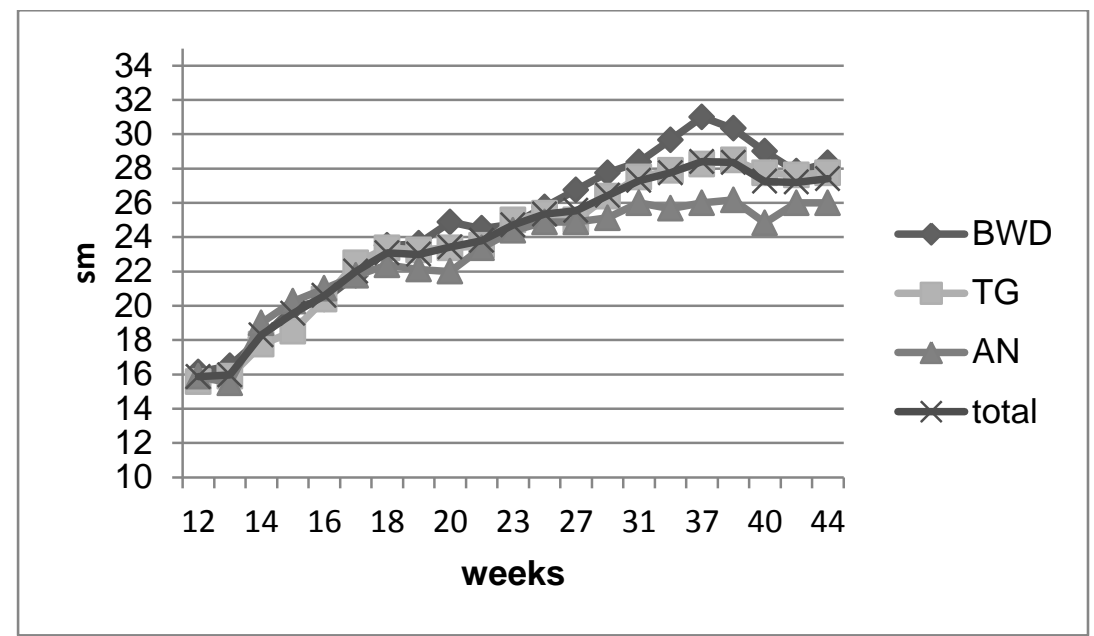

Figure 1. Value of the circumference of the scrotum

Table 1. Minimum and maximum values and coefficient of variation for scrotum circumference of all studied animals at different ages, $n=12$.

\begin{tabular}{|l|l|l|l|}
\hline $\begin{array}{l}\text { Age, } \\
\text { weeks }\end{array}$ & $C V \%$ & $\min$ & $\max$ \\
\hline 12 & $11,00 \%$ & 12,50 & 19,50 \\
\hline 13 & $13,32 \%$ & 13,00 & 21,00 \\
\hline 14 & $10,96 \%$ & 15,50 & 23,50 \\
\hline 15 & $11,92 \%$ & 16,00 & 24,00 \\
\hline 16 & $10,50 \%$ & 17,00 & 25,00 \\
\hline 17 & $9,74 \%$ & 18,00 & 25,50 \\
\hline 18 & $10,92 \%$ & 19,00 & 28,50 \\
\hline 19 & $8,39 \%$ & 20,00 & 27,00 \\
\hline 20 & $9,01 \%$ & 20,50 & 27,00 \\
\hline 21 & $6,97 \%$ & 21,00 & 26,50 \\
\hline 23 & $7,59 \%$ & 22,00 & 28,50 \\
\hline 25 & $6,80 \%$ & 22,50 & 29,00 \\
\hline 27 & $7,25 \%$ & 22,50 & 28,50 \\
\hline 29 & $6,03 \%$ & 24,00 & 29,00 \\
\hline 31 & $5,60 \%$ & 25,00 & 29,50 \\
\hline 35 & $7,89 \%$ & 24,50 & 31,00 \\
\hline 37 & $9,12 \%$ & 25,00 & 33,00 \\
\hline 39 & $8,88 \%$ & 25,50 & 32,00 \\
\hline 40 & $8,79 \%$ & 23,50 & 30,50 \\
\hline 42 & $6,55 \%$ & 23,50 & 29,50 \\
\hline 44 & $9,14 \%$ & 22,00 & 30,50 \\
\hline
\end{tabular}

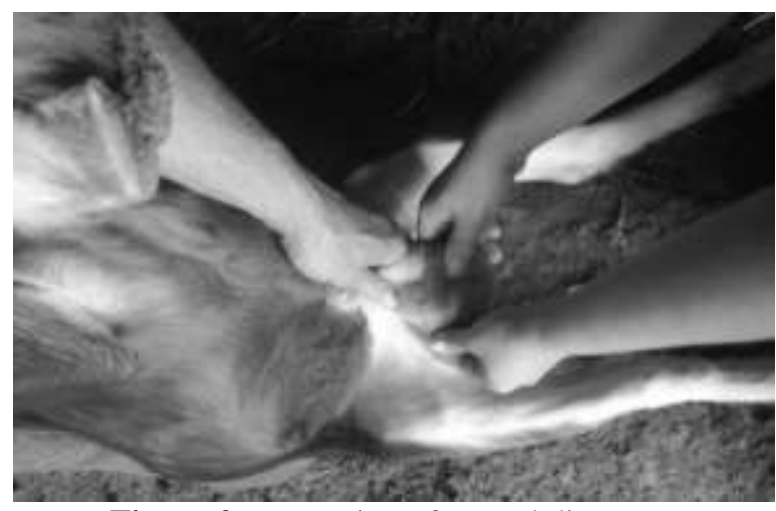

Figure 2. Measuring of scrotal diameter.

Trakia Journal of Sciences, Vol. 19, № 1, 2021 


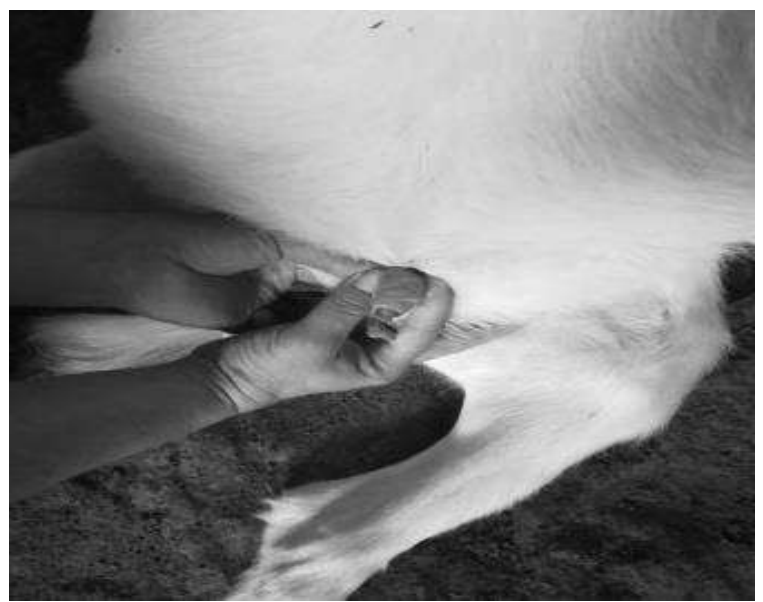

Figure 3. Monitoring the release of the penis from the foreskin

Table 2 presents the age, live weight and circumference of the scrotum according to the development of the penis

Table 2. Age, live weight and circumference of the scrotum according to the development of the penis.

\begin{tabular}{|l|l|l|l|l|l|l|l|l|l|}
\hline & \multicolumn{3}{|l|}{ Bulgarian White Dairy, $\mathrm{n}=4$} & \multicolumn{2}{l|}{ Togenburg, $\mathrm{n}=4$} & \multicolumn{2}{l|}{ Anglo-Nubian, $\mathrm{n}=4$} \\
\hline & $\begin{array}{l}\text { age } \\
\text { weeks }\end{array}$ & weight kg & $\begin{array}{l}\text { scrotal } \\
\text { circumference } \\
\text { sm }\end{array}$ & $\begin{array}{l}\text { age } \\
\text { weeks }\end{array}$ & weight kg & $\begin{array}{l}\text { Scrotal } \\
\text { circumference } \\
\text { sm }\end{array}$ & $\begin{array}{l}\text { age } \\
\text { week } \\
\text { s }\end{array}$ & weight kg & $\begin{array}{l}\text { scrotal } \\
\text { circumference } \\
\text { sm }\end{array}$ \\
\hline 1 & 10 & $22,13 \pm 0,47$ & & 10 & $19,75 \pm 0,83$ & & 10 & $18,85 \pm 1,66$ & \\
\hline 2 & 13 & $23,1 \pm 0,32$ & $16,17 \pm 0,44$ & 13 & $20,6 \pm 0,69$ & $15,58 \pm 0,58$ & 15 & $22,68 \pm 1,2$ & $15,5 \pm 1,89$ \\
\hline 3 & 14 & $24,17 \pm 0,35$ & $16,33 \pm 0,44$ & 15 & $22,68 \pm 1,2$ & $15,88 \pm 0,52$ & 20 & $25,9 \pm 1,73$ & $21,75 \pm 1,56$ \\
\hline 4 & 15 & $26,40 \pm 0,51$ & $18,17 \pm 0,93$ & 17 & $24,23 \pm 1,32$ & $17,75 \pm 0,43$ & 22 & $30,8 \pm 0,81$ & $22,13 \pm 0,77$ \\
\hline 5 & 16 & $27,9 \pm 1,12$ & $19,4 \pm 1,3$ & 18 & $25,9 \pm 1,73$ & $18,5 \pm 1,04$ & 24 & $32,25 \pm 0,85$ & $24,38 \pm 0,8$ \\
\hline
\end{tabular}

According to (13) testicular hormones affect the separation of the penis from the foreskin. Many studies in the available literature consider the age of separation of the foreskin from the penis as the age of puberty.

The earliest complete release of the penis in our study was observed in the male kids Bulgarian White Dairy breed -16 weeks, which coincides with the beginning of the first period of stability in the size of the circumference of the scrotum. Togenburg kids reached full release at - 18 weeks and with them this period coincides with a period of stability in testicular growth. In Anglo-Nubians kids, the release was at -24 weeks at which the live weight and diameter of the scrotum were at their highest. Unlike the other two breeds, the complete release of the penis from the foreskin in AngloNubian kids coincides with the second period of stability in testicular growth. Our studies confirmed the findings of (14) in young male kids of the Anglo-Nubian breed that the separation of the penis from the foreskin begins slightly at $10-12$ weeks of age, which is preceded by a peak in testosterone levels. The second peak in the level of the steroid is followed by its complete release, which takes place between the ages of 22 and 24 weeks.An earlier complete release of the penis from the foreskin was reported by (15) in crossbred young male kids (Anglo-Nubian x Saanen 16.3 weeks) and (4) in Anglo-Nubian young male kids (102 days).

Birth and weaning weight is an indicator that can serve as a guide in the selection of breeders. Factors such as breed, age, individual characteristics, productive direction, nutrition, season, etc. may affect changes in live weight.

The change in weight of male kids from birth to 44 weeks is shown in Figure 4. Their diet and the conditions under which the experimental animals were kept were the same. In this way, we reject nutrition as a factor influencing the change in weight of individuals in the experimental groups. It can be seen that the weight of the kids increases within the breed with increasing age. 


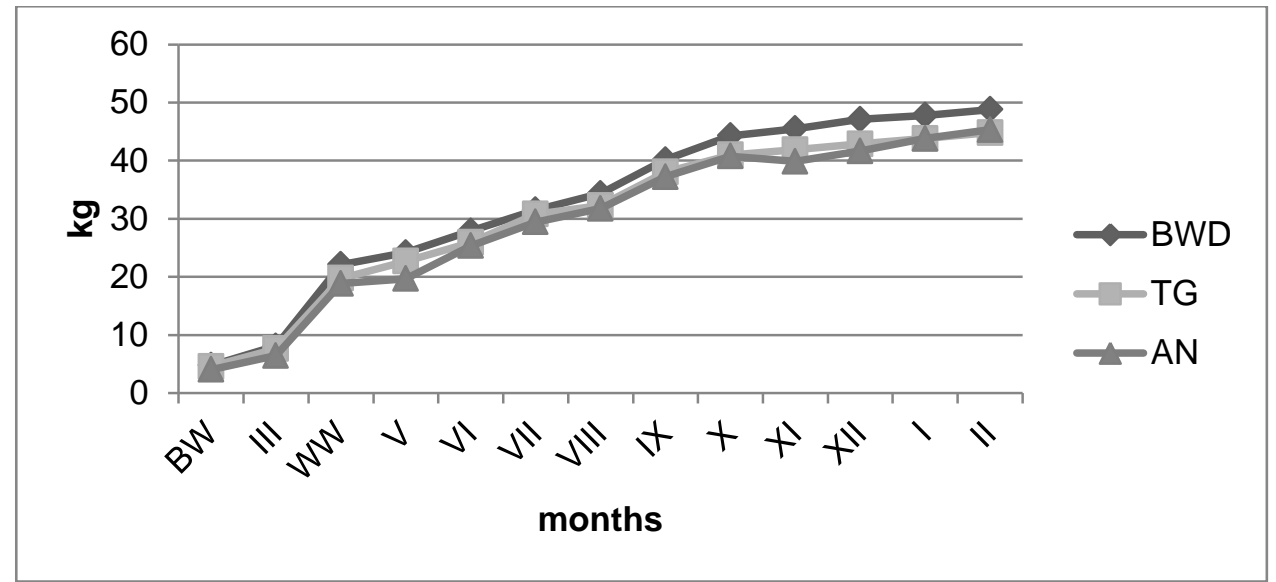

Figure 4. Weight change by breed during the study period.

In the period after weaning, there was slight retention in all three studied breeds, which in our opinion is due to the stress of moving animals and the formation of different groups. In crossbred young bucks (Anglo-Nubian $\mathrm{x}$ Saanen) (15) found values close to ours: average birth weight $-3.80 \pm 0.14 \mathrm{~kg}$, average live weight at weaning $-14.4 \pm 0.73 \mathrm{~kg}$, and average weight at puberty (7.5 months) -22.38 $\pm 0.94 \mathrm{~kg}$.

Table 3. Pearson correlation coefficient between morphological characteristics according to kids breeds

\begin{tabular}{|l|l|l|l|l|}
\hline & $\begin{array}{l}\text { stages of release } \\
\text { of the penis from } \\
\text { the foreskin }\end{array}$ & $\begin{array}{l}\text { scrotal } \\
\text { age, } \\
\text { weeks }\end{array}$ & $\begin{array}{l}\text { weight } \\
\text { kg }\end{array}$ & $\begin{array}{l}\text { circumference } \\
\text { sm. }\end{array}$ \\
\hline Bulgarian White Dairy, $\mathbf{n}=\mathbf{4}$ & $\mathbf{1}$ & & & \\
\hline $\begin{array}{l}\text { stages of release of the penis from the } \\
\text { foreskin }\end{array}$ & $\mathbf{0 , 9 6 2 * * *}$ & $\mathbf{1}$ & & \\
\hline age, weeks & $\mathbf{0 , 9 8 8 * * *}$ & $\mathbf{0 , 9 1 7} * *$ & $\mathbf{1}$ & \\
\hline weight kg & $\mathbf{0 , 9 2 6 * *}$ & $\mathbf{0 , 8 1 1 *}$ & $\mathbf{0 , 9 7 2 * * *}$ & $\mathbf{1}$ \\
\hline scrotal circumference sm & & & & \\
\hline Togenburg, $\mathbf{n} \mathbf{4}$ & $\mathbf{1}$ & & & \\
\hline $\begin{array}{l}\text { stages of release of the penis from the } \\
\text { foreskin }\end{array}$ & $\mathbf{0 , 9 8 5 * * *}$ & $\mathbf{1}$ & & \\
\hline age, weeks & $\mathbf{0 , 9 9 4 * * *}$ & $\mathbf{0 , 9 6 8 * * *}$ & $\mathbf{1}$ & \\
\hline weight kg & $\mathbf{0 , 9 6 5 * * *}$ & $\mathbf{0 , 9 5 8 * * *}$ & $\mathbf{0 , 9 5 0 * *}$ & $\mathbf{1}$ \\
\hline scrotal circumference sm & & & & \\
\hline Anglo-Nubian, $\mathbf{n}=\mathbf{4}$ & $\mathbf{1}$ & & & \\
\hline $\begin{array}{l}\text { stages of release of the penis from the } \\
\text { foreskin }\end{array}$ & $\mathbf{0 , 9 7 5 * * *}$ & $\mathbf{1}$ & & \\
\hline age, weeks & $\mathbf{0 , 9 9 1 * * *}$ & $\mathbf{0 , 9 7 7 * * * *}$ & $\mathbf{1}$ & \\
\hline weight kg & $\mathbf{0 , 9 4 8 * *}$ & $\mathbf{0 , 9 5 8 * * * *}$ & $\mathbf{0 , 9 3 5 * *}$ & $\mathbf{1}$ \\
\hline scrotal circumference sm & & & \\
\hline
\end{tabular}

$* \mathrm{P}<0.05, * * \mathrm{P}<0.01, * * * \mathrm{P}<0.001$

The correlation coefficient showed a very strong reliable positive relationship between the studied factors in all three studied breeds (Table 3). The stages of release of the penis from the foreskin were positively correlated with increasing age, live weight and circumference of the scrotum. The scrotal circumference was also positively affected by age and weight. Our findings coincided with the research of (4) in Anglo-Nubian bucks as 
they observed a high positive relationship ( $\mathrm{r}=$ 0.94) between live weight and scrotal circumference. The results obtained were confirmed by (16) in White Borno young bucks ( $r=0.82)$ and (17) in bucks of the Boer breed $(r=0.78)$ as the mentioned researchers have worked at different latitudes. (7) Reported similar results for the correlation between live weight and scrotal circumference in Boer bucks born during the dry $(r=0.93)$ and rainy seasons $(\mathrm{r}=0.88)$. (18) Also reported that in the study of Savanah brown bucks, the size of the scrotal circumference was influenced by age and live weight. When (4) analyzed comprehensively these findings, they conclude that regardless of breed and latitude, testicular growth was closely related to live weight and age of the bucks.

According to (7) the scrotal circumference is directly related to body weight and testosterone concentration, regardless of the season in which the animals were born. In adolescent male goats, the sudden increase in scrotal circumference coincides with the onset of spermatogenesis (19).

(20) Reported maximum levels of plasma protein (PRL), testosterone, LH, FSH reaching between 18-20 weeks, which gives them reason to define this age as puberty in bucks.

The present study confirmed earlier observations of the first signs of puberty. However, the age at which sexual maturity occurs in the goat breeds we study must be confirmed by more research, which will be the subject of future research.

\section{CONCLUSIONS}

It was found that the early signs of puberty of male kids in the breed Bulgarian White Dairy appeared at the age of 16 weeks and scrotal diameter $19.4 \mathrm{~cm}$, in the Togenburg breed at the age of 18 weeks and scrotal diameter 18.5 $\mathrm{cm}$, and in the Anglo-Nubian breed 24 weeks and scrotal diameter $24.38 \mathrm{~cm}$.

A very strong reliable positive relationship between the stages of penile release, scrotal circumference, live weight and age was confirmed in all three studied genotypes.

Testicular size and body weight could be used as a determining factor in the selection of prepubertal male kids.

\section{ACKNOWLEDGMENT}

This work was supported/(partially supported) by the Bulgarian Ministry of Education and
Science under the National Research Programme "Reproductive biotechnology in animal husbandry in Bulgaria (NPP REPROBIOTECH)" approved by DCM \# 577 / 17.08.2018".

\section{REFERENCES}

1. Kolev, A. and Dicheva L. Study on the reproductive characteristics of rams of some breeds. grown in our country. I. Morphological studies on the development of the testes of rams of the Black-headed Pleven breed. Animlal science, XXIV, (10): 9-16, 1987 (in BG)

2. Pacheco, A., Oliveira, A.F.M., Quirino, C.R. and Landim, A. V. Características seminais de carneiros da raça Santa Inês na prépuberdade, puberdade e na póspuberdade, Ars Veterinária, 25, (2): 90-99, 2009 (In Portuguese)

3. Alves, J. M., McManus, C., Lucci, C. M., Carneiro, H. C. R., Dallago, B. S., et al. Estação de nascimento e puberdade em cordeiros Santa Inês. Rev Bra Zoo. 35: 958966, 2006 (In Portuguese)

4. De Souza L. E. B., Ferreira da Cruz J., Rezende Teixeira Neto M., et al. Puberty and sexual maturity in Anglo-Nubian male goats raised in semiintensive system. Rev Bras Zoo, 40, (7): 1533-1539, 2011

5. Akpa, G. N., Ambali, A. L. and Suleiman, I. O. Body Conformation, Testicular and Semen Characteristics as Influenced by Age, Hair Type and Body Condition of Red Sokoto Goat. New York Science journal, 6, (7): 44-58 2013

6. De La Vega, A., Ruiz, R. and Wilde, O. Relación de la circunferencia escrotal con algunos parámetros de calidad seminal en caprinos Criollos de Tucumán (Argentina). Zootecnia Tropical,19: 455- 463, 2001 (In Spanish)

7. Bezerra, F.Q.G., Aguiar Filho, C.R., Freitas Neto, L.M., Santos Junior, E.R., et al. Body weight, scrotal circumference and testosterone concentration in young Boer goat males born during the dry or rainy seasons. South African Journal of Animal Science, 39, (4): 301-306, 2009

8. Mule, M.R., Barbind, R.P. and Korake, R.LRelationship of body weight with linear body measurement in Osmanabadi goats, Indian Journal of Animal Research, 48: 155-158, 2014

9. Patni M., Singh S. K., Singh D. V., Palod J., Kumar A., Singh M. K. and Sathapathy S. Studies on body weight, body 
measurements and scrotal morphology in local Pantja goats, Indian Journal of Animal Research, 50, (1): 105-111, 2016

10.Hoflack G., Van Soom A, Maes D., De Kruif A., Opsomer G. and Duchateau L. Breeding soundness and libido examination of Belgian Blue and Holstein Friesian artificial insemination bulls in Belgium and The Netherlands, Theriogenology, 66: 207216, 2006

11.Perumal P. Scrotal Circumference and Its Relationship with Testicular Growth, Age, and Body Weight in Tho Tho (Bos indicus) Bulls. International scholarly research notices, 249537. https://doi.org/10.1155/2014/249537, 2014

12.Wiggins E. L.and Terrill C. E. Variation in Penis Development in Ram Lambs, Journal of Animal Science, 12, (3): 524-535, 1953

13.Eloy, A.M.X. and Santa Rosa, J.SPerfis plasmáticos de testosterona durante a puberdade de machos caprinos da raça Moxotó. Pesquisa Agropecuária Brasileira, 33: 1645-1652, 1998 (In Portuguese)

14.Abdelrahman, S. S., Makawi A. E. S., Tingari D. M. and Eltayeb A. E. A. Association of body weight, scrotal circumference, heart girth and penile development with spermatogenesis in the Nubian bucks. Journal of Veterinary Medicicne and Animal Health, 10, (9): 217223, 2018
15.Elhammali, N. S. A., Abdulrahman A. M., Mohamed I. T. and Adil E. S. Puberty of crossbred male goat kids. Journal of American Scence, 9, (4): 95-97, 2013

16.Raji, A. O., Igwebuike and Aliyu J. Testicular biometry and its relationship with body weight of indigenous goats in a semi arid region of Nigeria. Journal of Agricultural and Biological Science, 3, (4): 6-9, 2008

17. Keith C. O., S Solaiman and O Tiller Accuracy of predicting body weights from body conformation and testicular morphormetryin pubertal Boer goats. Research Journal of Animal Science, 3, (2): 26-31, 2009

18. Shoyombo A., Fasanya O., Bunjah U. and Yakubu H. On- Farm Prediction of Testicular Characteristics in Bucks at Specific Ages, World Journal of Life Science and Medical Research, 2: 114-117, 2012

19.Bongso, T. A., Jainudeen, M. R. and Siti Zahrah, A. Relationship of scrotal circumference to age, body weight and onset of spermatogenesis in goats. Theriogenology, 18, (5): 513-24, 1982

20.Abdelrahman, S.S., Abdalla, M.S., Darderi, T.M., and Ali, E. Development of hormonal profiles of Nubian bucks at puberty in Sudan. Journal of Veterinary Medicine and Animal Health, 11: 106-114, 2019 